\title{
Explanation and Chronology of Megalithic Tombs in North-Western Iran \\ (Based on the Excavations of the Scythian Cemetery in Khorram Abad), Meshgin Shahr*
}

\author{
Ali Navidgabalou**, Reza Rezalou***, \\ Karim Hajizadeh $^{* * * *}$, Behrooz Afkhami ${ }^{* * * * *}$
}

\begin{abstract}
The ancient cemetery of Khorram Abad is located $7 \mathrm{~km}$ away from Meshgin Shahr in Ardabil province. During the excavations, relics of Iron Age I, II and III and also tombs (1500 to 550 BC) have been found. Iron Age I and II tombs are of the type of Megalithic cemetries. The Scythians were a nomadic tribe that spread over a wide geographical area, from the Black Sea in the west to the borders of China. The most important relics of these tribes were their barrows, which can help us understand their political, economic, artistic and worldview. Therefore, for studying tombs, various factors such as the way of distribution of tombs, the shape and form of tombs, burial in tombs, objects and gifts placed in tombs can be very closely related to the culture of people or a region. According to the conducted excavations, this article has pursued three important goals: 1-Typologically, in how many categories can the tombs of this cemetery be classified? 2- What was the relationship between these tombs and the sites of the surrounding settlements, if any, and can the existence of a community with a ruling structure be deduced from the structure and contents of the tombs? 3- What are the analytical comparison and typology of these tombs with their similar types in Iran and abroad? The remains of these barrows have been excavated outside the geographical territory of Iran in the south of Caucasus and around the Black Sea, Russia and Kazakhstan, the most important of which are Pazyryk, Arrajan (Russia) and Kostromskaya. It seems that Khorram Abad's cemetery had an important religious context used over a wide period of time.
\end{abstract}

\footnotetext{
* This article has been taken from Mr. Ali Navidgabaloo 's dissertation entitled "Typology and study of the structure of megalithic tombs in northwestern Iran", which was conducted at University of Mohaghegh Ardabili.

** $\mathrm{PhD}$ student of Archaeology, University of Mohaghegh Ardabili, Ardabil, Iran. Email:arjann122@gmail.com

${ }^{* * *}$ Full Professor, Department ofArchaeology,University of Mohaghegh Ardabili, Ardabil, Iran. E-mail:reza_rezaloo@yahoo.com

**** Associate Professor, Department ofArchaeology,University of MohagheghArdabili, Ardabil, Iran. E-mail:k_hajizadeh@uma.ac.ir

***** Associate Professor, Department ofArchaeology,University of MohagheghArdabili, Ardabil, Iran. E-mail: Bafkhami@uma.ac.ir
} 
Keywords: Northwest, MeshginShahr, Khorram Abad's Cemetery, Scythian tribes, burial.

\section{Introduction}

Tomb architecture can reflect the culture and religion of a community or region in a particular period of time. Also, the architecture and location of the tomb indicate the position and the status of the deceased in society. In the Iron Age, we encounter different types of tomb structures, some of which are specific to a particular area. In the North-West, due to its strategic geographical location and the fact that this region has witnessed extensive relations with neighboring regions during the period, it has been subject to inevitable effects and has led to a variety of burial methods. In any case, the burial rites have resulted from the religious rites of the tribes. Religion is inextricably linked to burial rites, and burials are always a clear sign of a society's religion. The Scythian tribes were nomadic people who had magnificent burial rites. In most of the Scythian burials, discovered during archaeological excavations until now, undoubtedly, there is a special burial behavior that differs only in some minor cases. One of the prominent features of Scythian burials was the presence of a horse as a victim next to the deceased. This animal has a special value and importance among Scythian tribes. The Scythians had a special respect for their ancestors and created large and magnificent tombs for them. Many samples of them were discovered in the south of Russia, Tuva, Northern Mongolia, Altai and Siberia, Northern Caucasus, Northern Black Sea, Southern Ukraine. Distinctive samples of Scythian tombs have been obtained during the archaeological excavations of Khorram Abad cemetery in Meshgin Shahr, one of the cities of Ardabil province, which is very similar to the samples obtained from Scythian cemeteries in Central Asia and the North Caucasus.

\section{Iron Age cemeteries in North-Western Iran}

Cemeteries and vestiges related to burial rite are one of the most important archaeological data to identify the various aspects of the lives of ancient tribes. Probably the most common way to reconstruct the social structure of ancient societies is to use data from ancient burials ${ }^{1}$. Both the architecture of the tombs and the historical relics inside them can depict man's thoughts and how he thinks about death. They also provide information on the economy, type of living, social classes, and ethnography. The shape and depth of the tomb can be related to the social status or gender of the deceased, as well as

\footnotetext{
${ }^{1}$ Ken Dark, Theoretical Foundations of Archaeology, 2000, p. 11.
} 
to whether the ceremony is formal or informal ${ }^{2}$. In the Near East, especially in Iran, around the $8^{\text {th }}$ millennium $\mathrm{BC}$, the human left burial remains under residential houses, ruins near the residence or as separate cemeteries by establishing permanent settlement and reliance on an economy based on agriculture and animal husbandry. In some periods of Iran, especially Iron Age, due to nomadic life or special climatic and cultural conditions, most of our information about the lives of these people are obtained through cemeteries. Therefore, the data of the cemetery obtained from the Neolithic period to the present provide very valuable information to archaeologists and anthropologists for understanding the various dimensions of social, economic, religious, political and military life, climate change, human diseases, etc. These data have a special place in archeology due to the close relationship with daily life and human thought and belief ${ }^{3}$.

The North-Western region of Iran is very important in terms of Iron Age studies. Extensive excavations in this region have revealed different dimensions of the Iron Age more than other regions of the Iranian plateau. Unlike North-Central Iran, in the North-West, in addition to cemeteries not related to the region of settlements (Dinkhah, Blue Mosque of Tabriz and Yaniq Tappeh), cemeteries related to the region of settlements (Hasanlu and Haftavan) have also been studied ${ }^{4}$. According to the studies conducted in the North-Western region of Iran, four main groups have been identified, each of which has the following subsets:

\section{1) pit tombs or simple holes}

Simple pit tombs

Pit tombs with stone covering

\section{2) Megalithic tombs}

Kurgan tombs

Four stratum tombstones (round cairn around the tomb)

Chest Tombs (with standing stone)

Dolmen tombs

\section{3) Brick tombs}

Four stratum brick tombs

Tombs with horizontal brick structures

Tombs with horseshoe structure (triangular)

\footnotetext{
${ }^{2}$ Mike Parker Pearson, The Archaeology Of Death And Buril, Sutton Publishing Limited, 1999 , p. 5.

${ }^{3}$ Alireza Hojabri Nobari and Akbar Poor Faraj, "Suggestions on how to excavate in cemeteries ....", 2005, p. 66.

${ }^{4}$ Hassan Talaei, Iron Age of Iran, Samat Publications, Tehran, 200, P. 130.
} 


\section{Jar tombs}

Before introducing the analysis of the tombs of the intended sites, considering the importance of the subject under study, first, the two terms of Megalithic and Kurgan are explained.

\section{Megalithic tombs}

Megalithic consists of two words of mega (large), Lithic (stone and of stone). Therefore, this term refers to tombs that have large stones in their structure, and because the construction of these tombs emerged with such structures in the period between the end of the $3^{\text {rd }}$ millennium to the end of the $1^{\text {st }}$ millennium BC and maybe by certain tribes (when talking about tribes, it should always be borne in mind that a nation is equal to a particular culture, and because we assume that these tombs were built by certain tribes, therefore, this type of tomb construction should be considered as a culture originated from those tribes)), it can be called a Megalithic culture ${ }^{5}$. Megalithic tombs are generally referred to as tombs that are made of large pieces of stone. These pieces can be used in different sizes and naturally (dressed) or not dressed. In tombs, large stones have been worked vertically, which form the integrated walls inside the tomb.

\section{Kurgan tombs}

The word "kurgan" was used by Gimbutas in 1956 and is a broad archaeological term used to describe the culture of semi-sedentism peoples in the steppes of Southern Russia. The word Kurgan has been used by Russian archaeologists to mean barrow ${ }^{6}$, Gimbutas divides this culture into three periods:

1- The Ancient Kurgan Period (Kurgan I) around 4200 - 4400 BC

2- The Middle Kurgan Period (Korgan II) around 3400 - 3600 BC

3- The New Kurgan Period (Korgan III) around 2800 - 3000 BC

According to Gimbutas, Kurgan is known to people who had a pastoral and semi-agricultural life. They had a patriarchal society with a special hierarchy, and in the region of settlements, there were significant Tepe Qale as the center of the tribe, around which a temporary village with semiunderground houses was built. They were horse-riding people. This animal played an important role in their lives. They had special burial ceremonies and rituals, burying their dead in cottage-like tombs made of stone and wood and filling it with large stones or dirt as a clear sign. They had the symbol of

\footnotetext{
${ }^{5}$ Vida Ebtehaj, Investigation of the Structure of Megalithic Tombs in the Iron Age of Iran: A Case Study of Shahar Yeri Site in Ardabil Province, 2004, P. 201.

${ }^{6}$ Gimbutas, Chronologies of Eastern Europe: Neolitic Throughly Bronz Age, 1992, P. 401.
} 
the horse, the sun and the snake. An important point in their burial was the choice of burial direction towards the $\operatorname{sun}^{7}$

\section{Kurgan barrow, Maikop barrow and Trialeti barrow}

In the late $3^{\text {rd }}$ millennium $\mathrm{BC}$, a new burial tradition appeared in Georgia that had previously existed in the Northern steppes, but they were completely unfamiliar with the area under the influence of the culture beyond the Old Caucasus and the rest of the Near East in this time period. ${ }^{8}$

The Scythians had Kurgan tombs, consisting of a rectangular tomb with a structure of large stones in the middle and a circular arrangement of stones that defined its boundaries. The first Scythian tombs were also on the same surface of the earth and cairn was made around them in a circle; but around $1200 \mathrm{BC}$, this burial method changed and the Scythians began to build hills on the tombs ${ }^{9}$. These circular revetments around the tomb have long been used to build tombs. In the large areas of the Altai Mountains and the ancient sites of Dejazato and Ustide, traces of this type of burial can be seen, which consists of a round or oval shaped environment of large circular stones with a predominantly rectangular tomb. ${ }^{10}$ The emergence of a special Scythian culture in the late Bronze and early Iron Ages, along with a particular artistic style and various tomb structures, indicates an unknown type of social stratification ${ }^{11}$. The prevalence of early kurgans dates back to $2500 \mathrm{BC}$, which indicates a lifestyle based on nomadism and animal husbandry ${ }^{12}$. According to the studies and excavations carried out in different regions, it can be stated that the end of the Old Bronze Age and the beginning of the Middle Bronze Age faced significant changes, including changes in the settlement pattern based on nomadism and animal husbandry ${ }^{13}$, progress in the metalworking industry, new burial traditions and rites, the use of chariots and the depopulation of areas and instead settlement in the highlands ${ }^{14}$.

\footnotetext{
${ }^{7}$ Gimbutas, op. cit, 402.

${ }^{8}$ Charles Burney, The Peoples of the Hills: Ancient Ararat and Caucasus, 1971, P. 77.

${ }^{9}$ Tamara Rice, Scythians, 1991, P. 30.

${ }^{10}$ Bourgeois and Gheyle, The Frozen Tombs of the Altai Mountais, Survey and inventory of archaeological sites and permafrost occurrence in the Dzhator valley, 2005, p. 11.

${ }^{11}$ Chagunov et all, The Golden Tomb from Arzhan, 1995, p. 41.

${ }^{12}$ Sagona, Social boundaries and ritual landscapes in late prehistoric tranc-Caucasus and highland Anatolia in a view from the highlands, 2004.

${ }^{13}$ Adam Smith et all, Early Complex Societies in Southern Caucasia: A Preliminary Report on the Tsakahovit Plain, Republic of Armenia, 2003, p. 10.

${ }^{14}$ Puturidze, Social and Economic Shifts in the South Caucasian Middle Bronze Age. pp.111127. In: Archaeology in the borderlands: in verstigations in Caucasia and beyond, edited by A.T .Smith and K., 2003, p. 114.
} 
These kind of tombs were sometimes made in different shapes and forms that had stratified or stone structures with different plans such as horseshoe, Lshaped, triangular and quadrangular. Four stone walls can be seen in these tombs. For building them, at first a rectangular piece of land, with a length and width between $150-200$ to $180-120 \mathrm{~cm}$ with a depth of about 50 to 100 $\mathrm{cm}$, was dug and after excavation and creating the desired space on the wall, the appearance of the side wall was made by available stones. If it was close to the mountains, mountain rocks were used, and if there was a river near the cemetery, the existing rocks were used. The walls of these tombs had usually been made in two ways: either the walls were made of small stones in the form of locks and straps, which is usually more common in mountainous areas, or the walls were made of several cadavers. However, both types have been seen in plains and non-mountainous areas. The reason for the difference in the structure of the four-stratum tombs is simply the appearance of the stone used in their construction. In some mountainous areas, where the rocks are extracted in the form of relatively large flat sheets, each of the four sides of the tomb wall was blocked by a piece of those rocks, which is placed vertically. But what is the same in both types of tombs is the cover on the tombs. It means that the stones were selected in a way that covered the entire width of the tomb and their two ends were placed on the longitudinal walls. Until now, no prehistoric cemetery has been found to have the tombstone carved or smoothed. What attracts attention in these tombs is their width, which is relatively less than the tombs in which rubbles were used. The reason was simply the lack of access to stones with the appropriate volume and intended length and width. The point is that throughout the territory of Iran, in tombs with flat cover, the distance and crevice between large stones were blocked by smaller stones and even small and large cobblestones. In the $1^{\text {st }}$ millennium, there was a type of four-stratum tomb whose surface cover was hidden under a crust of soil and the area of the tomb on the ground was marked with medium cobblestones in the form of an irregular oval or circle ${ }^{15}$ One of the main features of Kurgan culture is the use of large monolithic stones to build tombs. Nowadays, within the borders of Iran, these tombs can be found around peripheral castles belonging to the New Bronze and Iron I period in East Azerbaijan ${ }^{16}$ and Ardabil province ${ }^{17}$ in abundance.

\footnotetext{
${ }^{15}$ Nusratullah Motamedi, Burial rituals in Lorestan, first millennium BC, 1986, pp. 3-36.

${ }^{16}$ Kamaluddin Niknami and Mehdi Kazempour, Archaeological Report on Determining the Privacy of Zardkhaneh Site, 2011.

${ }^{17}$ Reza Rezalou, , The Emergence of Societies with a Complicated Political and Social Structure in the New Bronze Age in the Southern Basin of the Aras River with a Case Study of the Archaeological Data of Khosrow Castle, 2007.
} 
This type of tomb (Kurgani) has been identified in the overseas regions in Anatolia from the Middle Bronze Age to the Iron $\mathrm{I}^{18}$, in the Republic of Azerbaijan belonging to the Middle and New Bronze Age and in Armenia from the Middle Bronze Age to the Iron Age $\mathrm{I}^{19}$.

\section{Background of studies in Ardabil province}

For the first time, between 1899 and 1901, Jacques de Morgan explored several cemeteries around the city of Namin in the province of Ardabil, which had four-stratum megalithic tombs. He excavated cemeteries around the town of Namin, next to the villages of Soli Darreh, Chilakhaneh, Vajalik, Lordaghi, Chaghala Darreh, Tash Kopro, Hassan Zamini, Khorkhor, Chirchir and Chirchirpuri, and suggested a new Bronze Age history for these cemeteries. He also excavated in the cemeteries of Khoja Davood Kopro on the road of Namin to Astara, the cemetery of Qale Beyg in the southwest of Astara and in the Khalkhal and Talesh areas in the cemeteries of Agh-Uler, Dukhalian and Ganjkhaneh ${ }^{20}$. Shaeffer, considering the cylindrical seals obtained from Hassan Zamini and Agh-Uler cemeteries and comparing them to the similar samples obtained from Mesopotamia, suggested the dates of 15 and $14 \mathrm{BC}$ for these cemeteries ${ }^{21}$. The German archeological delegation who conducted archaeological studies in East Azerbaijan (in areas such as Jolfa plain, Marand, Tabriz, Maragheh, Miyaneh, Sarab, Ardabil, Garmi, Ahar and Meshgin Shahr) for many years (1967, 1968, 1971 and 1978), proposed the history of the New Bronze Age and the Middle and Old Iron Age for these cemeteries based on the earthen data obtained from these cemeteries ${ }^{22}$. During the archeological excavations of the British delegation headed by Charles Burney in the city of Meshgin Shahr, a countless number of fourstratum Megalithic tombs had been mentioned, but due to time constraints, only 16 samples of these tombs had been recorded. One of the sites studied at this time was the Pirazmeyan site ${ }^{23}$. Saifullah Kambakhshfard, in his studies in some parts of Nayr and Sarab villages, mentions two sites. One of these sites is Tikili Dash Cemetery, located one kilometer North of Narmiq village,

\footnotetext{
${ }^{18}$ Kusnareva, The Southern Caucasus in Prehistory, The University Museum University of Pennsylvania Philadelaphia, 1997.

${ }^{19}$ Adam Smith, op. cit.

${ }^{20}$ Demorgan, J., Recherches au Talych Persaen 1901, pp. 267-305.

${ }^{21}$ Shaeffer, S. A., Stratigraphie comparé et chronologie de l'Asie occidentale, London: Oxford University Press, 1948, p. 408.

${ }^{22}$ Kleiss, Beridt uberzwei er Kundun gsfahrten in Nordwest - Iran, 1969, pp. 188- 191.

${ }^{23}$ Ingraham and Summer, Stelae and Settlement in the Meshkin Shahr Plain, North-Eastern Azerbaijan Iran, 1979, pp. 68- 69.
} 
at the foot of Mount Bozgush, and the other is Qarah Shiran Cemetery in Ardabil. These cemeteries had been looted in ancient times ${ }^{24}$. In 2003, Mrs. Vida Ebtehaj studied the collection of tombs in Pirazmeyan site in her master's thesis ${ }^{25}$, after which the excavations of Dr. Hejbari Nobari began in this site $^{26}$. In the studies conducted between 2000-2003 by Dr. Rezalou, a member of the Faculty of Mohaghegh Ardabili University in the provinces of East Azerbaijan and Ardabil, a collection of castles with the names of Khosrow, Zino, Shender Shami, Gol Nesa, Kichik Yordi, Shaitan Dashi and Qale-Yeri were studied. Next to these castles, the cemeteries are of the type of four-stratum tombs with round cairn ${ }^{27}$.

The owners of this type of tombs were settled in Azerbaijan and part of East Gilan at the foothills, and due to the proximity of the mountains and the use of stone, they built their tombs in the best and largest possible way. Fourstratum megalithic tombs have a long history, spread in a wide geographical area from the coasts of Mazandaran to the West and North-West of Iran at different time intervals and. This type of tombs has spread not only in large numbers in the Talesh region belonging to the Iron Age I, Northern Iran belonging to the $1^{\text {st }}$ millennium $\mathrm{BC}^{28}$, North-West ${ }^{29}$ and Western Iran, but, in the neighboring countries such as Anatolia ${ }^{30}$, Armenia ${ }^{31}$ (Fig. 1) and the Republic of Azerbaijan, the existence of such tombs, from the Old Bronze Age to the Old Iron Age, has been proven (Fig. 2). Around Lake Urmia, there are also tombs with a stone structure belonging to the Bronze and Iron Ages in areas such as: Goy Tape (Tomb K) ${ }^{32}$ Dinkhah $^{33}$, Haftavan Tepe (with traces of defensive walls belonging to the middle of the second millennium $\mathrm{BC}$ with a number of tombs) has been identified ${ }^{34}$.

\footnotetext{
${ }^{24}$ Saifullah Kambakhsh Fard, Tehran, Three Thousand and two hundred years old based on archaeological excavations, 1991, p. 123.

${ }^{25}$ Vida Ebtehaj, op. cit.

${ }^{26}$ Masoud Azarnoush, "Recent Archaeological Research in Iran Prehistory to Iron Age", Barbara Helwing, 2005, PP. 216.

${ }^{27}$ Reza Rezalou, op. cit, p. 2.

${ }^{28}$ Mohammad Reza Khalatbari, Archaeological Excavations in Talesh sites, 2004, pp. 116117.

${ }^{29}$ Rubinson, A Mid-Second Millennium Tomb at DinkhaTepe, 1991, p. 390.

${ }^{30}$ Kusnareva, op. cit.

${ }^{31}$ Adam Smith, op. cit.

${ }^{32}$ Dyson, Problems of Protohistori Iran as Seen from Hasanlu, 1965, p. 196.

${ }^{33}$ Muscarella, The Iron Age at Dinkha Tepe, Iran, 1974, p. 35.

${ }^{34}$ Talaei and Aliyari, Iranica Antiqua, 2009, p. 89.
} 


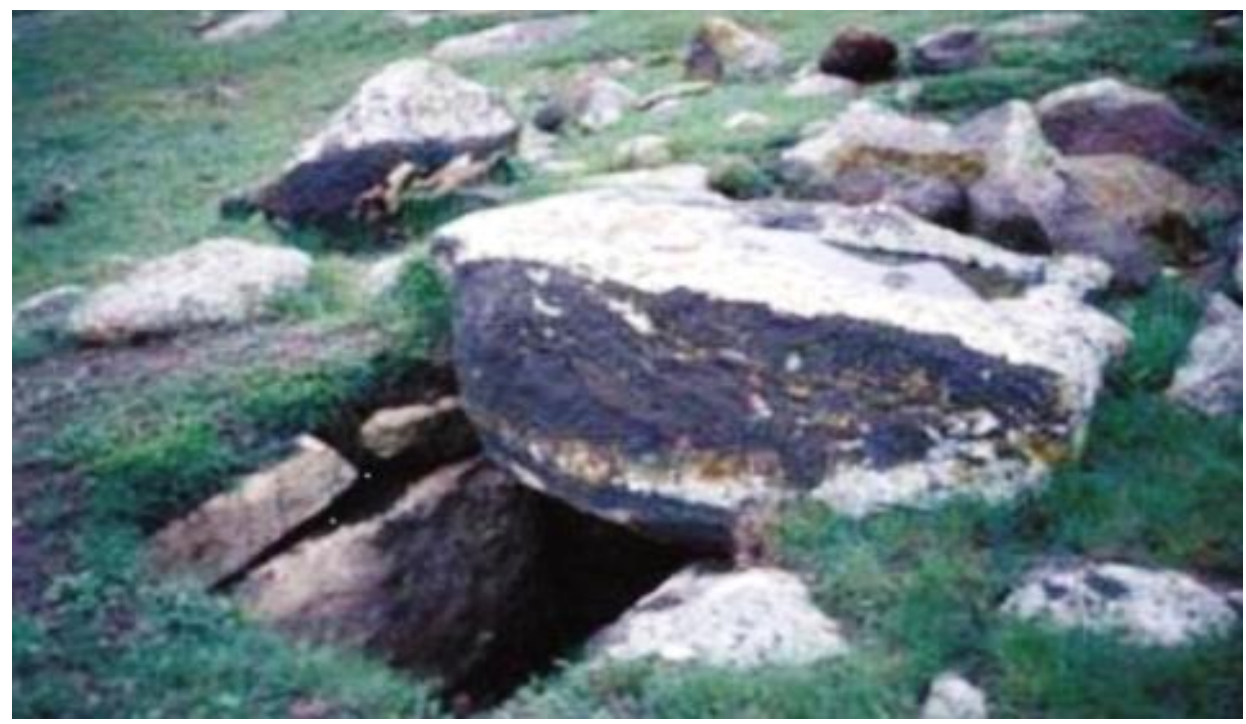

fig. 1 Kurgan tomb

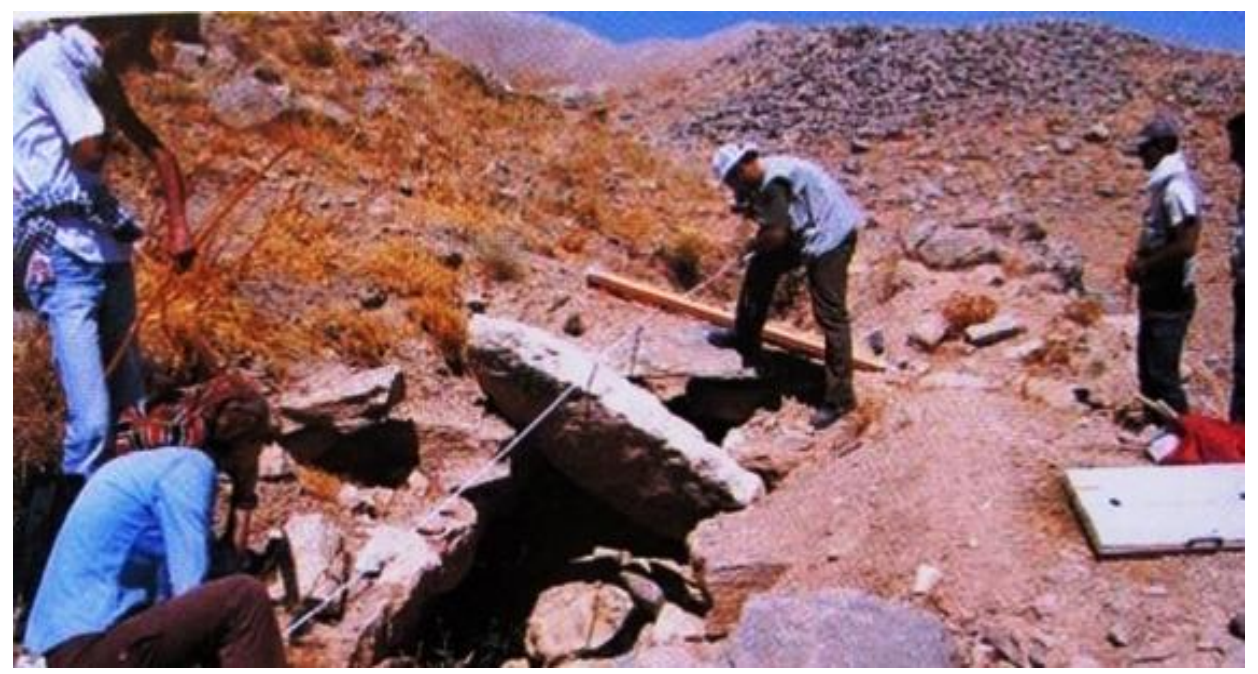

fig. 2 Kurgan tomb from Nakhchivan

\section{Khorram Abad Cemetery}

For the first time in Iran, tombs belonging to the Scythian tribes were found during the excavations of the ancient cemetery of Khorram Abad in Meshgin Shahr. The excavation of this site was a type of rescue excavation that started on January 4, 2017 and was carried out until February 4, 2018 for 5 months. 
The ancient cemetery of Khorram Abad is located $7 \mathrm{~km}$ away from Meshginshahr in Ardabil province. This site is located 300 meters south of Khorram Abad village (Fig. 3). During the excavations, relics of Iron Age I, II and III tombs (1500 to $550 \mathrm{BC}$ ) have been found. Iron Age I and II tombs are of the type of Megalithic cemetries (Fig. 4). These tombs are made of very large boulders with stone structure. In this way, at first, the tomb pit was dug to the desired dimensions and the walls and ceiling were worked with boulders with dimensions of 1.5 to 3.5 meters, which were cut in single face. These tombs were built in the East-West direction and their length varies from 4.5 to 6 meters and their width varies from 2 to 3 meters (Fig. 2). In these tombs, mass burials have been performed at different levels, so that in one of the tombs, 19 human skeletons have been found. These burials seem to have taken place over several generations. For this purpose, the western wall of these tombs has been used to open and close and place new burials. In addition to human skeletons, animal burials including dogs can be seen in these tombs. Gifts placed in these tombs include bronze and iron objects, ceramic and a variety of ornaments.

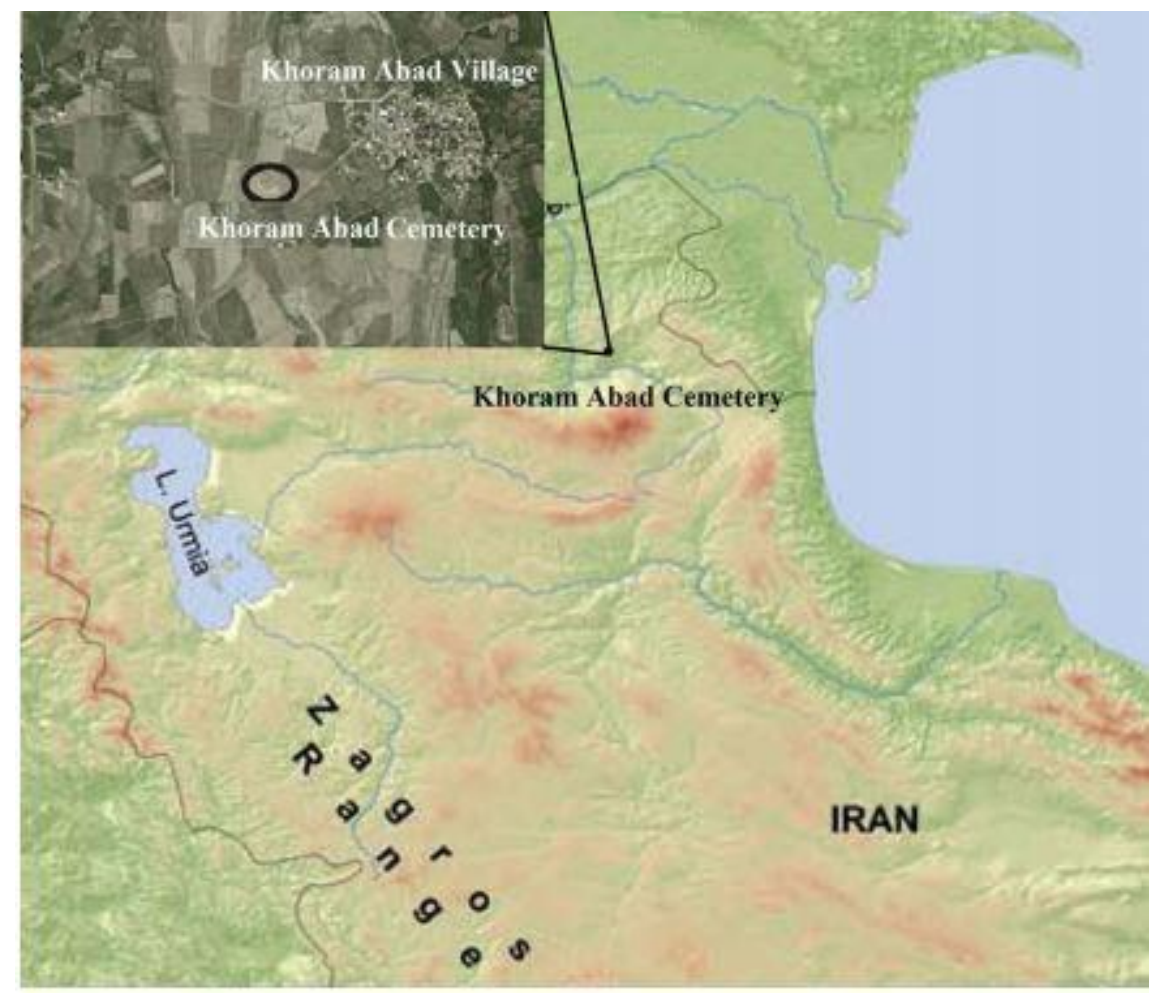

fig. 3 Location of Scythian Khorram Abad Cemetery 


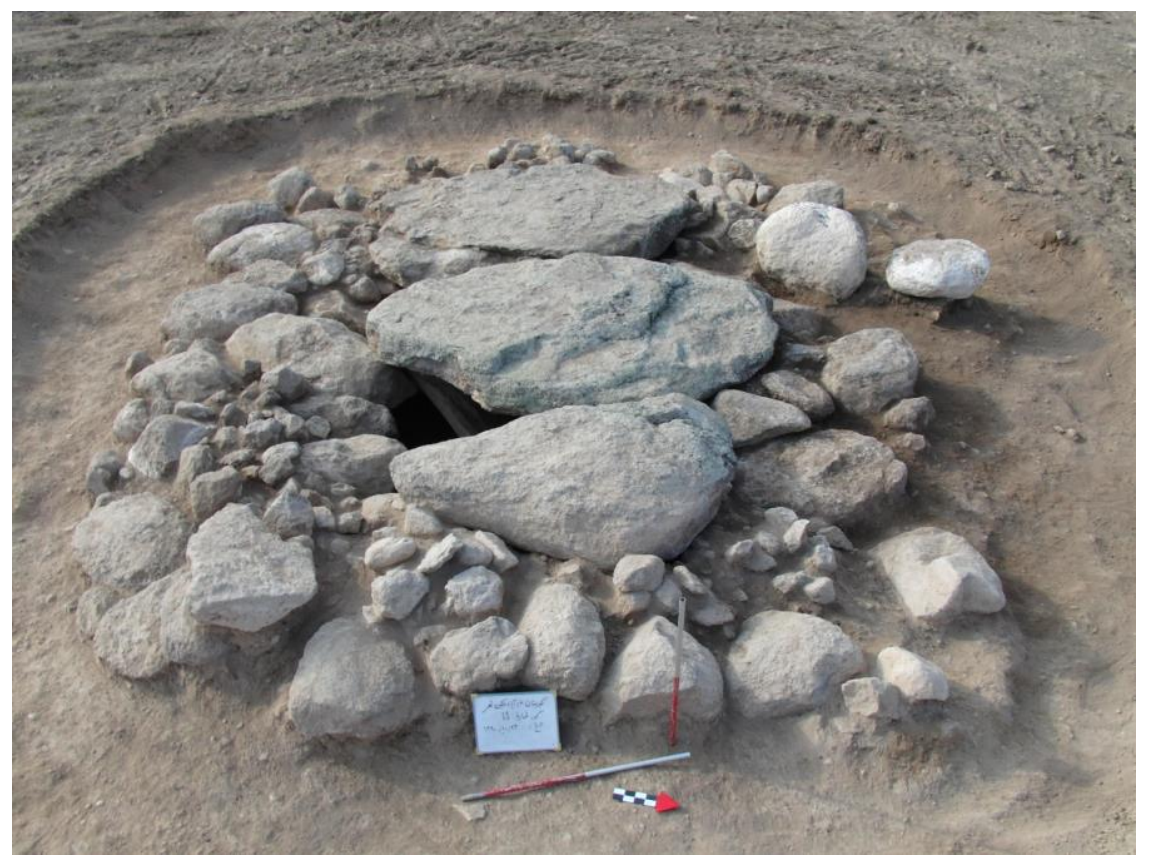

fig. 4 One of the Megalithic tombs related to the Iron Age of Khorram Abad Cemetery

\section{Tomb 22}

This tomb was a type of pit tomb whose Northern and Southern walls were made with stratum on a stone foundation and its roof was covered in timber. This tomb is one of the most unique tombs in Iran and it was built according to the tradition of burying horses in this tomb. The data obtained from this tomb during scientific research belong to the Scythian tribes and this tomb can be possiblly attributed to one of the Scythian princes or nobles. The general shape of the tomb is rectangular and its direction is East-West (Fig. 5). Around the tomb, there are small remnants of the circular mansory of the tomb. In the floor of the tomb, a kind of flooring can also be seen, which seems to have been created with a kind of washed and clean soil, and it seems that this floor has been pounded. The interesting point of this tomb is that it was looted in its time and after the completion of the burial operation, because the human skeleton obtained from inside the tomb was very disturbed and also the gifts were not obtained regularly on one level. Remains of animal sacrifices have been found in the soil poured on the tomb and in the Western part of the tomb. These vows and sacrifices seem to have belonged to a horse obtained in scattered and fragmented form. A sheep and a cow frame were also obtained. In addition, the bones of birds can be seen 
scattered in this area. An interesting point is that gifts including bronze and iron objects and countless decorative beads of ferrite, agate and gold have been obtained among these sacrifices ${ }^{35}$. One of the most important gifts discovered in this tomb during the excavation was the skull and parts of the skeleton of a horse (Image 6) and a horseshoe (Image 7) next to the tomb. Another valuable data of these tombs are potteries, which can be attributed to the Scythian tribes based on the method of their construction and decoration. These potteries have engraving geometric motifs. The interior of these motifs was filled with white material, a method which is specific to the Scythians and has been identified in many Scythian sites (Fig. 8).
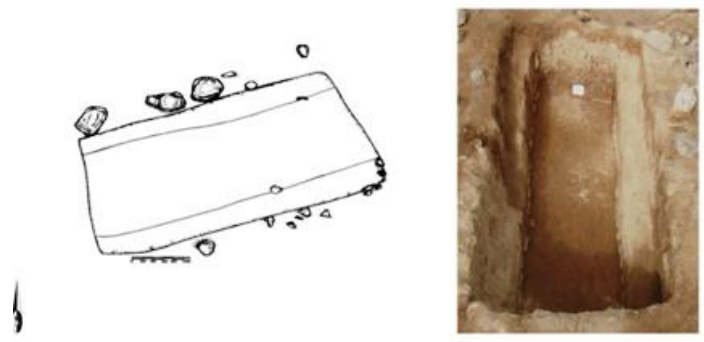

B22
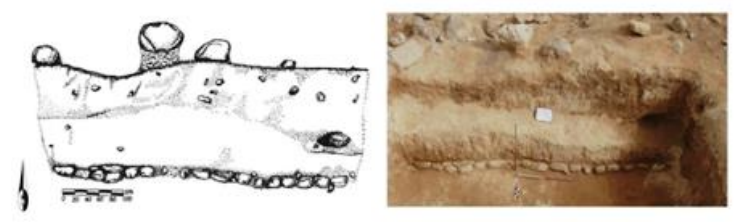

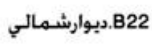

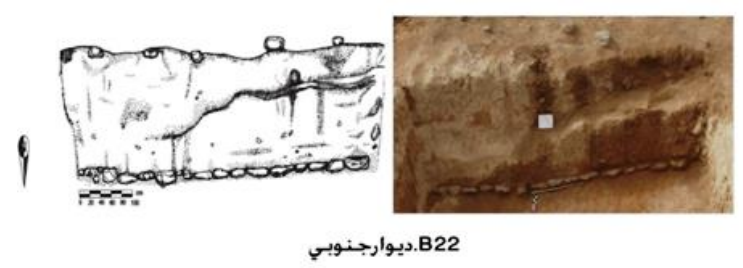

Fig. 5: Tomb 22, North and South walls with stratum on a stone foundation

\footnotetext{
${ }^{35}$ Reza Rezalou and Hamid Khanali, Scythian Burials of Khorram Abad Cemetery in Meshgin Shahr, 2014.
} 


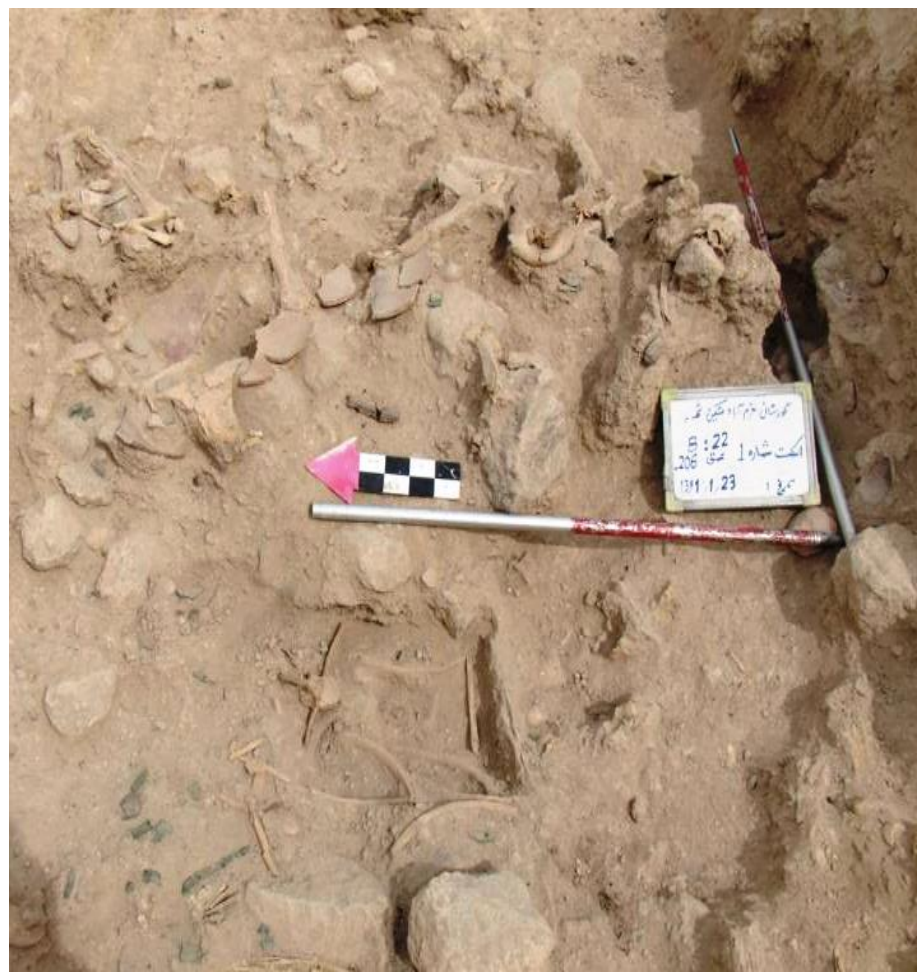

Fig. 6 Tomb 22, the main burial with scattered horse bones

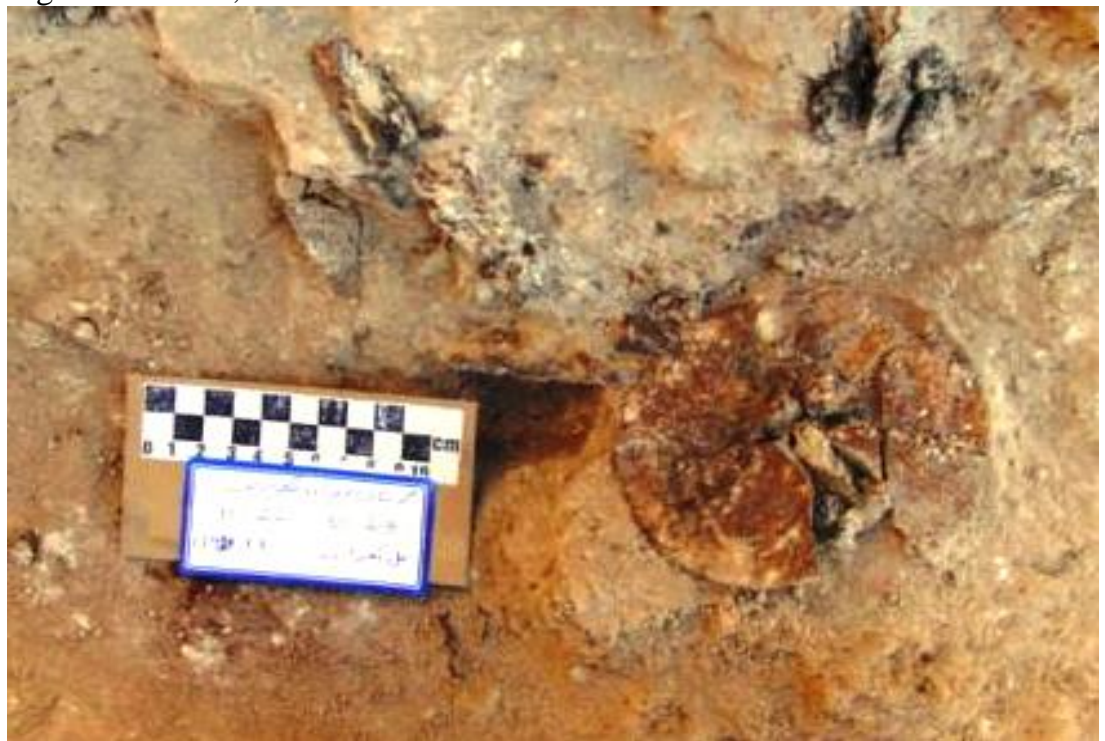

Fig. 7 Iron horseshoe discovered from Tomb 22 

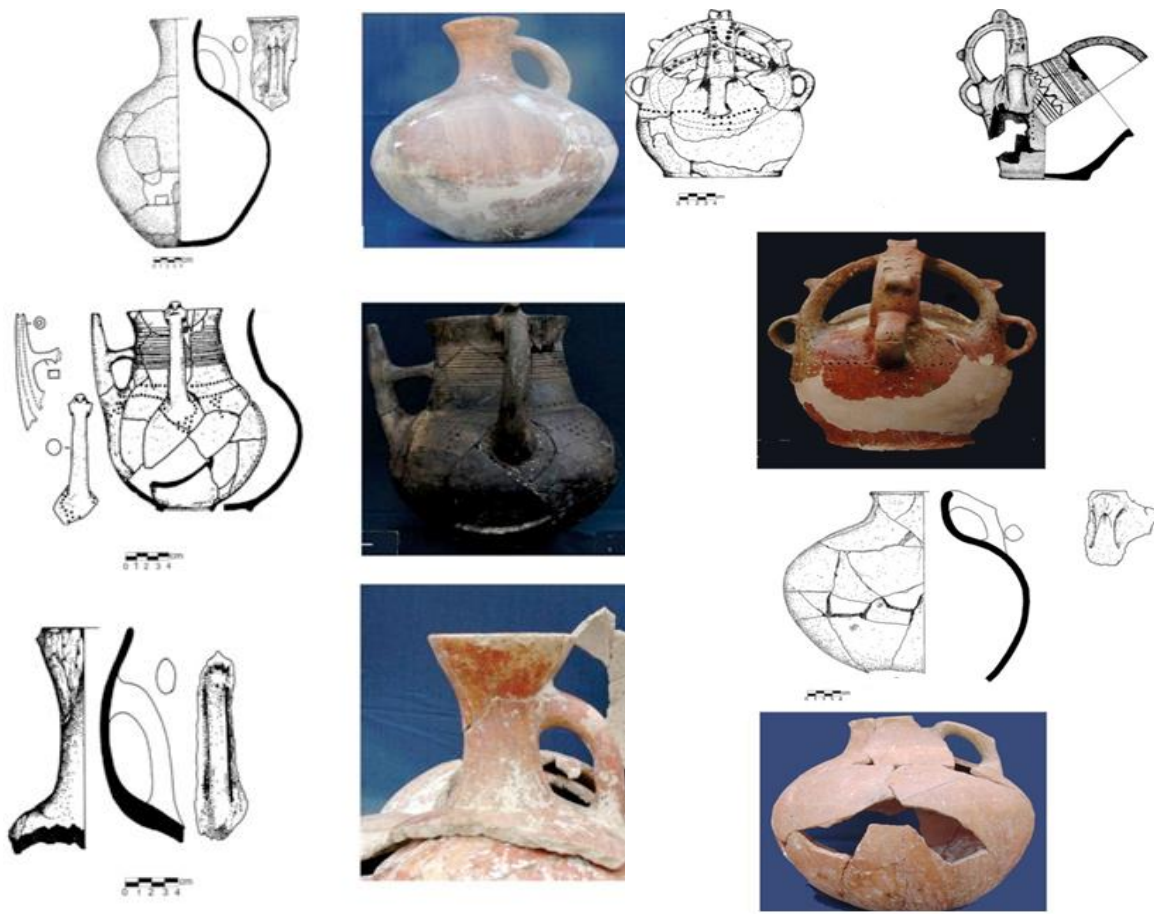

Fig. 8 Potteries discovered from Tomb 22

\section{Tomb 21}

This tomb is located in the Western part of Tomb 22. It belongs to a part of the gifts given to the person buried in Tomb 22. Four burials were found in this tomb, all of which belonged to women (Fig. 9). The skeletons were in a very bad condition and only a few parts of them were left. They seem to have been buried secondarily, in such a way that after death or after being killed, either they were placed in another place and after the passage of time and after the corpse rots and separates from the bone, they were transferred to this place, or these people were killed and their organs and body parts were cut and buried in this place. Another factor of losing most of these skeletons was the rocky bed on which the skeletons had been placed. Skeleton 1 belonged to a 30-35 years old woman buried in the East-West direction. Skeleton 2 belonged to a woman aged 18 to 22 years. Skull 3, which belonged to a woman between the ages of 20 and 25, was located on the North-West side of skeleton 1 . Skull 4 belonged to a woman aged between 40-45. Only two ceranics were obtained from this tomb (Fig. 10). The first was a mediumnecked ceramic located in the South-Western part of the tomb. The second one is a closed mouth located in the Northern part of the tomb ${ }^{36}$.

\footnotetext{
${ }^{36}$ Reza Rezalou and Maryam Bayrami, Architecture of the Kurgans of Northwestern Iran", 2016, p. 6.
} 

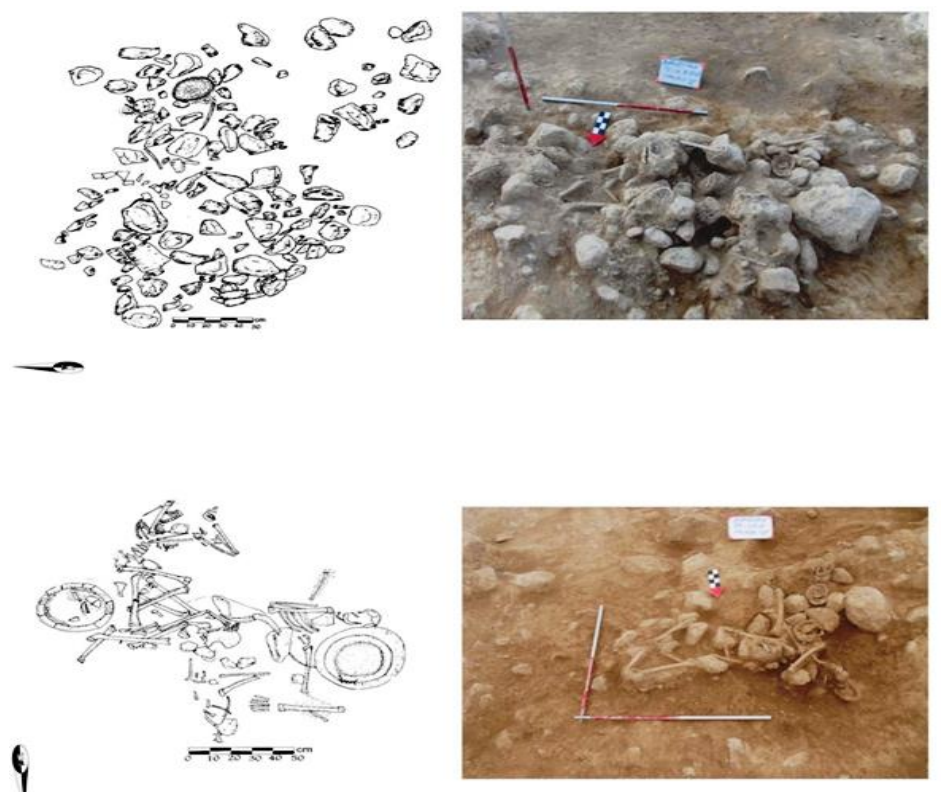

Fig. 9 Tomb 21 - skeleton of sacrified women for the deceased in the main tomb
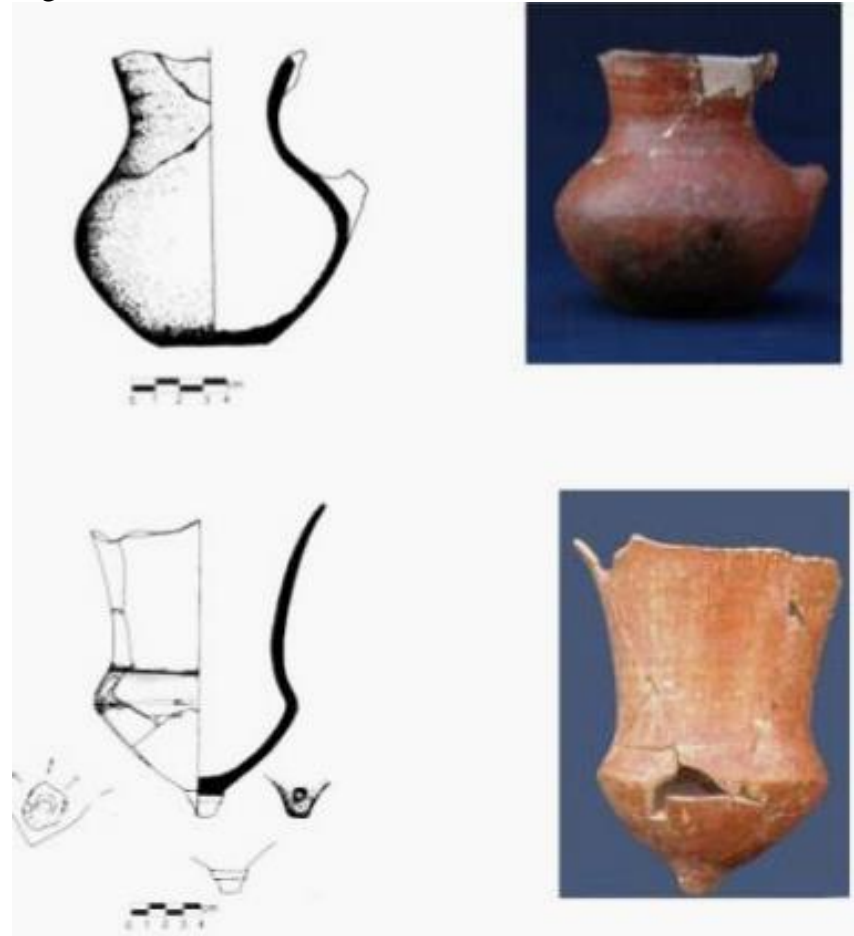

Fig. 10 Potteries belong to Tomb 21 


\section{Tomb 20}

This tomb is located 7 meters distance from the North of Tomb 21 and 22. During the excavation in this tomb, 34 horse skeletons were found, which is one of the most unique findings discovered and identified from Khorram Abad cemetery (Fig. 11). These horses seem to have been gifts given to the person buried in Tomb 22. One of the main reasons why most of the horses buried in the Scythian kurgans remain intact and healthy is that the burials of the horses are usually located on the margin of these sites, so their tombs were less destroyed by thieves. Also, the number of them depends on the condition of the private and wealthy tombs. The tomb pit were made in the shape of an oval and the dimensions and space needed to place the bodies of the horses were dug. An irregular row of cairn has been created on the ground, and by pouring a mixture of rock and soil on the desired tomb, they changed the form of tomb surface into a small mound. It should be noted that to prevent the roof from falling on the skeletons, the surface of the tomb was covered with timber, which rotted over time and settled into the tomb. The effects of these timbers are completely visible on the tomb. The burial of the horses has been done on two levels or in two irregular rows, so that 17 horses have been buried in the first level and 18 heads in the second level. It seems that no special direction has been observed in their burial. The most interesting point about this tomb is that none of these horses showed any signs of killing in them and it seems that these horses were first strangled and then buried. The decorative beads were the only gifts obtained alongside the skeletons. They were made of ferrite or glass and hung around the neck or legs of the skeleton.

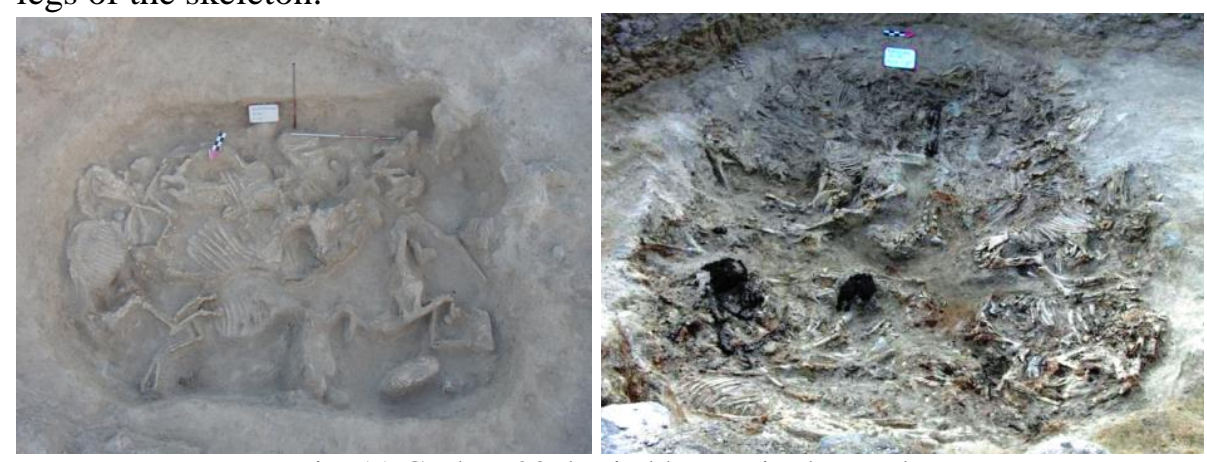

Fig. 11 Gurkan 20, buried horses in the tomb.

\section{Discussion and conclusion}

According to the researches and excavations carried out by archaeologists in the last few decades, it can be stated that the material cultures of the Scythians in the Western regions are quite comparable to the samples obtained from the steppes of Central Asia. Some pieces, such as horseshoes, weapons, bronze pots, mirrors and objects made in the style of animals all 
represent Scythian culture and art. There are even common points about burying horses on top of each other and their number. Comparative analysis of Scythian kurgans shows the diversity of burial rites. But in some cases, there are significant similarities in burials and Scythian burials rites. For example, the tombs were made in the shape of kurgan or barrow. These tombs were made in the shape of a circle. In some cases, stone was used to create mound on the tomb, and it was also used to create rings around burial or burial pit walls. Soil and stone and a combination of both were usually used to construct and create tombs. The main burial was located in the central part of the burial and was for East-West burial. Stone was mostly used for covering burial tomb, and changed it into the form of bulkhead. Wood was rarely used to cover the roof. Sometimes, one or more burials were made in a kurgan around the main tomb. The burial of horses and related objects can be seen in most Scythian tombs. What is important in the Scythian cemetery of Khorram Abad is that the burial of horses, unlike other similar examples, was placed on both sides and next to the tomb of the deceased instead of being on the burial of the deceased. On the main tomb, we encounter the bones of the sacrified people, who dismembered their corpse after being killed. This method of Scythian burial is one of the rare examples in West Asia. One of the most common objects inside the tombs are potteries, which are sometimes simple and unadorned, and in some cases, decorated with engraving geometric motifs. The interior of these motifs was filled with white material. The most important achievement of this season of excavation is the creation of burial barrows belonging to the Scythian elders. Of course, some scholars also attribute the treasure of Ziwiye to one of the Scythian princes. In the tombs of Khorram Abad cemetery, both the burial of horses and human sacrifices can be seen, and considering that the burial of horses had not taken place in the burials of the ordinary people of these tribes, it can be said that these tombs belong to Scythians elders and princes. The Scythians were a nomadic tribe that spread over a wide geographical area, from the Black Sea in the West to the borders of China. The relics of these barrows have been excavated outside the geographical territory of Iran in Southern Caucasus, around the Black Sea, Russia, and Kazakhstan, the most important of which are Pazyryk, Arjan (Russia) and Kostromskaya. It seems that Khorram Abad cemetery has an important religious context used by Scythian tribes for a wide period of time. 


\section{List and source of illustrations:}

Fig. 1 Kurgan tomb, Adam Smith, op. cit.

Fig. 2 Kurgan tomb from Nahçivan, Oktay Belli and Veli Bahşaliyev, Nahçivan Blgesinde, Arkeolojive Sanat Yayinlari, Middle and Late Bronze Age Painted Pottery Culture in the Nakhichevan Region, 2001, p. 140.

Fig. 3 Location of Scythian Khorram Abad Cemetery, Reza Rezalou and Yahya Ayramlou, Horse Burial Ritual among Scythian Tribes: Case Study of Khorram Abad Cemetery in Meshgin Shahr, Historical Sociology, 2014, fig.1.

Fig. 4 One of the Megalithic tombs related to the Iron Age of Khorram Abad Cemetery

Fig. 5 Tomb 22, North and South walls with stratum on a stone foundation Fig. 6 Tomb 22, the main burial with scattered horse bones

Fig. 7 Iron horseshoe discovered from Tomb 22

Fig. 8 Potteries discovered from Tomb 22

Fig. 9 Tomb 21 - skeleton of sacrified women for the deceased in the main tomb

Fig. 10 Potteries belong to Tomb 21, Reza Rezalou and Yahya Ayramlou, op. cit , p. 134.

Fig. 11 Gurkan 20, buried horses in the tomb.

\section{Sources and references:}

Azarnoush, Masoud, "Recent Archaeological Research in Iran Prehistory to Iron Age", Barbara Helwing, AMIT 37,PP. 189-246. 2005,

Belli, Oktay, Bahşaliyev, Veli, Nahçivan Blgesinde, Arkeolojive Sanat Yayinlari, Middle and Late Bronze Age Painted Pottery Culture in the Nakhichevan Region, Istanbul: Arkeolojive Sanat Yayinlari, 2001.

Bourgeois, J., Gheyle, w., The Frozen Tombs of the Altai Mountais, Survey and inventory of archaeological sites and permafrost occurrence in the Dzhator valley. Report on the Belgian Russian expedition in Alltai Republic: Russia, 2005.

Burney, Charles. A, The Peoples of the Hills: Ancient Ararat and Caucasus, David M. Lang, History of Civilization, New York: Praeger, 1971.

Chagunov, K., Naglar, A., Parzinger, H., The Golden Tomb from Arzhan, Russia, 39-42, 1995.

Dark ,Ken R., Theoretical Foundations of Archaeology, translated by Kamyar Abdi, University Publishing Center, 2000. 
Demorgan, J., Recherches au Talych Persaen 1901, pp. 251-345. In Necropoles des Ages du Fer, MOP VIII, 1905.

Dyson, R.H., Problems of Protohistori Iran as Seen from Hasanlu, JNES 24: pp. 193-217, 1965.

Ebtehaj, Vida, Investigation of the Structure of Megalithic Tombs in the Iron Age of Iran: A Case Study of Shahar Yeri Site in Ardabil Province, Tarbiat Modares University, Fall 2004.

Gimbutas, M., "Chronologies of Eastern Europe: Neolitic Throughly Bronz Age”, in Robert Ehrich, ed., Chronogiesin old wold. Vol 1., pp.395-406 Chicago: University of Chicago Press, 1992.

Hojabri Nobari, Alireza and Poor Faraj, Akbar, "Suggestions on how to excavate in cemeteries ....", Archaeological Message, Second Year, Fourth Issue, 2005.

Ingraham, M.L, and G. Summer., Stelae and Settlement in the Meshkin Shahr Plain, North-Eastern Azerbaijan, Iran, Archologische Mitteilungen aus Iran, 12: 67-101, 1979.

Kambakhsh Fard, Saifullah, Tehran, Three Thousand and two hundred years old based on archaeological excavations, Tehran, Faza Publication, Tehran, 1991.

Khalatbari, Mohammad Reza, Archaeological Excavations in Talesh sites, Guilan General Administration of Cultural Heritage, 2004.

Kleiss,W., Beridt uberzwei er Kundun gsfahrten in Nordwest - Iran. Archeologische Mitteilungen aus Iran 2:7-11, 1969.

Kusnareva, K. Kh., The Southern Caucasus in Prehistory, The University Museum University of Pennsylvania Philadelaphia, 22:138-149, 1997.

Motamedi, Nusratullah, "Burial rituals in Lorestan, first millennium BC", Forouhar Magazine, No. 5, 1986.

Muscarella, O.W., "The Iron Age at Dinkha Tepe, Iran" The Metropolitan Museum Journal, Vol. 9, pp.35-90, 1974.

Niknami, Kamaluddin and Kazempour, Mehdi, Archaeological Report on Determining the Privacy of Zardkhaneh Site, pp. 3-43, 2011.

Pearson, Mike Parker, The Archaeology Of Death And Buril, Sutton Publishing Limited, 1999.

Puturidze, M., Social and Economic Shifts in the South Caucasian Middle Bronze Age. pp.111-127. In: Archaeology in the borderlands: in verstigations in Caucasia and beyond, edited by A.T .Smith and K., 2003.

Rezalou, Reza and Ayramlou, Yahya, Horse Burial Ritual among Scythian Tribes: Case Study of Khorram Abad Cemetery in Meshgin Shahr, Historical Sociology, Volume 6, Number 3, 2014. 
Rezalou, Reza and Bayrami, Maryam, "Architecture of the Kurgans of Northwestern Iran", National Conference on Indigenous Architecture and Urban Engineering of Iran, Yazd, February 2016.

Rezalou, Reza and Khanali, Hamid, Scythian Burials of Khorram Abad Cemetery in Meshgin Shahr, first edition, pp.75-121, 2014.

Rezalou, Reza, The Emergence of Societies with a Complicated Political and Social Structure in the New Bronze Age in the Southern Basin of the Aras River with a Case Study of the Archaeological Data of Khosrow Castle, $\mathrm{PhD}$ thesis, Tarbiat Modares University, 2007.

Rice, Tamara, Scythians, translated by Roghayeh Hezadi, Tehran, Yazdan, 1991.

Rubinson, K. S., A Mid-Second Millennium Tomb at DinkhaTepe, American Journal of Archaeology, 95: 375-94, 1991.

Sagona, A., Social boundaries and ritual landscapes in late prehistoric tranc - Caucasus and highland Anatolia in a view from the highlands, Anes, Supplement, 12, pp.661-76, 2004.

Shaeffer, S. A., Stratigraphie comparé et chronologie de l'Asie occidentale, London: Oxford University Press, 1948.

Smith. Adam. T., Ruben. S. Badalyan and Pavel, A. Avetisyan, Early Complex Societies in Southern Caucasia: A Preliminary Report on the Tsakahovit Plain, Republic of Armenia, American Journal of Archaeology 108 (1): 1-42, 2003.

Talaei, Hassan, Iron Age of Iran, Samat Publications, Tehran, 2008.

Talaei, Hassan and Aliyari, A., Iranica Antiqua, XLIV, pp.89-120, 2009. 